ҚАЗАҚСТАН РЕСПУБЛИКАСЫ

ҰЛТТЫҚ ҒЫЛЫМ АКАДЕМИЯСЫНЫН

АБАЙ АТЫНДАҒЫ ҚАЗАҚ ҰЛТТЫҚ

ПЕДАГОГИКАЛЫҚ УНИВЕРСИТЕТІНІҢ

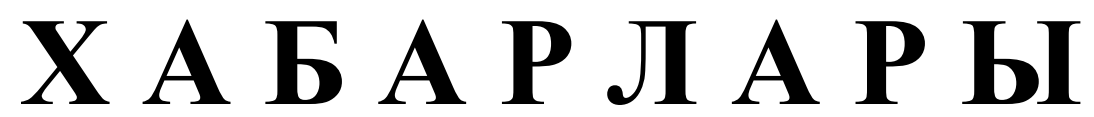

\section{ИЗВЕСТИЯ}

НАЦИОНАЛЬНОЙ АКАДЕМИИ НАУК РЕСПУБЛИКИ КАЗАХСТАН

КАЗАХСКИЙ НАЦИОНАЛЬНЫЙ

ПЕДАГОГИЧЕСКИЙ УНИВЕРСИТЕТ ИМ. АБАЯ

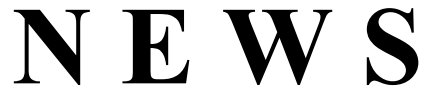

OF THE NATIONAL ACADEMY OF SCIENCES OF THE REPUBLIC OF KAZAKHSTAN

ABAY KAZAKH NATIONAL PEDAGOGICAL UNIVERSITY

ҚОҒАМДЫҚ ЖӘНЕ ГУМАНИТАРЛЫҚ ҒЫЛЫМДАР СЕРИЯСЫ

СЕРИЯ ОБЩЕСТВЕННЫХ И ГУМАНИТАРНЫХ НАУК

$\checkmark$

SERIES OF SOCIAL AND HUMAN SCIENCES

$$
5 \text { (321) }
$$

КЫРКУЙЕК - КАЗАН 2018 ж.

СЕНТЯБРЬ - ОКТЯБРЬ 2018 Г.

SEPTEMBER - OCTOBER 2018

1962 ЖЫЛДЫҢ ҚАНТАР АЙЫНАН ШЫҒА БАСТАҒАН

ИЗДАЕТСЯ С ЯНВАРЯ 1962 ГОДА

PUBLISHED SINCE JANUARY 1962

ЖЫЛЫНА 6 РЕТ ШЫҒАДЫ

ВЫХОДИТ 6 РАЗ В ГОД

PUBLISHED 6 TIMES A YEAR 
Ба с ре дактор

ҚР ҰҒА кұрметті мүшесі

Балықбаев Т.O.

Р е д а ц и я а лқ а сы:

экон. ғ. докторы, проф., ҚР ҰҒА академигі Баймұратов У.Б.; тарих ғ. докторы, проф., ҚР ҰҒА академигі Байпақов К.М.; филос. ғ.докторы, проф., ҚР ҰҒА академигі Есім Г.Е.; фил. ғ. докторы,, проф., ҚР ҰҒА академигі Қирабаев С.С.; эк. ғ. докторы, проф., ҚР ҰҒА академигі Кошанов А.К.; эк.ғ. докторы, проф., ҚР ҰҒА академигі Нәрібаев К.Н. (бас редактордың орынбасары); филос. ғ.докторы, проф., ҚР ҰҒА академигі Нысанбаев А.Н.; заң ғ. докторы, проф., ҚР ҰҒА академигі Сәбікенов С.Н.; заң ғ. докторы, проф., ҚР ҰҒА академигі Сүлейменов М.К.; эк. ғ. докторы, проф., ҚР ҰҒА академигі Сатыбалдин С.С.; тарих ғ. докторы, проф., ҚР ҰҒА академик Әбжанов Х.М.; тарих ғ. докторы, проф., ҚР ҰҒА корр. мүшесі Әбусеитова М.Х.; тарих ғ. докторы, проф., ҚР ҰҒА академик Байтанаев Б.А.; филол. ғ. докторы, проф., ҚР ҰҒА корр. мүшесі Жақып Б.А.; фил. ғ. докторы, проф., академик НАН РК Қалижанов У.К.; филол. ғ. докторы, проф., ҚР ҰҒА академик Қамзабекұлы Д.; тарих ғ. докторы, проф., ҚР ҰҒА академик Қожамжарова Д.П.; тарих ғ. докторы, проф., ҚР ҰҒА академик Койгелдиев М.К.; фил. ғ. докторы, проф., ҚР ҰҒА корр. мүшесі Кұрманбайұлы Ш.; тарих ғ. докторы, проф., ҚР ҰҒА корр. мүшесі Таймағанбетов Ж.К.; социол. ғ. докторы, проф., ҚР ҰҒА корр. мүшесі Шәукенова 3.К.; фил. ғ. докторы, проф., КР ҰҒА корр. мүшесі Дербісәлі А.; саяси. ғ. докторы, проф., Бижанов А.К., тарих ғ. докторы, проф., Кабульдинов 3.Е.; фил. ғ. докторы, проф., ҚР ҰҒА корр мүшесі Қажыбек Е.3.

\section{Р едакция ке н е с i:}

Молдова Республикасының ҰҒА академигі Белостечник Г. (Молдова); Әзірбайжан ҰҒА академигі Велиханлы Н. (Азербайджан); Тәжікстан ҰҒА академигі Назаров Т.Н. (Тәжікстан); Молдова Республикасының ҰҒА академигі Рошка А. (Молдова); Молдова Республикасының ҰҒА академигі Руснак Г. (Молдова); Әзірбайжан ҰҒА корр. мүшесі Мурадов Ш. (Әзірбайжан); Әзірбайжан ҰҒА корр. мүшесі Сафарова 3. (Әзірбайжан); э. ғ. д., проф. Василенко В.Н. (Украина); заң ғ. докт., проф. Устименко В.А. (Украина)

«Қазақстан Республикасы Ұлттық ғылым академиясының Хабарлары. Қоғамдық және гуманитарлық ғылымдар сериясы». ISSN 2224-5294

Меншіктенуші: «Қазақстан Республикасының Ұлттық ғылым академиясы» РҚБ (Алматы қ.)

Қазақстан республикасының Мәдениет пен ақпарат министрлігінің Ақпарат және мұрағат комитетінде 30.04.2010 ж. берілген № 10894-Ж мерзімдік басылым тіркеуіне қойылу туралы куәлік

Мерзімділігі: жылына 6 рет.

Тиражы: 500 дана.

Редакцияның мекенжайы: 050010, Алматы қ., Шевченко көш., 28, 219 бөл., 220, тел.: 272-13-19, 272-13-18, http://nauka-nanrk.kz. social-human.kz

(C) Қазақстан Республикасының Ұлттық ғылым академиясы, 2018

Типографияның мекенжайы: «Аруна» ЖК, Алматы қ., Муратбаева көш., 75. 
Главный редакто $p$

Почетный член НАН РК

T.O. Балыкбаев

Р е дак ци онн а я коллег и я:

докт. экон. Н., проф., академик НАН РК У.Б. Баймуратов; докт. ист. н., проф., академик НАН РК К.М. Байпаков; докт. филос. Н., проф., академик НАН РК Г.Е. Есим; докт. фил. Н., проф., академик НАН РК С.С. Кирабаев; докт. экон. Н., проф., академик НАН РК А.К. Кошанов; докт. экон. Н., проф., академик НАН РК К.Н. Нарибаев (заместитель главного редактора); докт. филос. н., проф., академик НАН РК А.Н. Нысанбаев; докт. юр. Н., проф., академик НАН РК С.Н. Сабикенов; докт. юр. н., проф., академик НАН РК М.К. Сулейменов; докт. экон. Н., проф., академик НАН РК С.С. Сатубалдин; докт. ист. н., проф., академик НАН РК Х.М. Абжанов; докт. ист. н., проф., чл.-корр. НАН РК М.Х. Абусеитова; докт. ист. н., проф., академик НАН РК Б.А. Байтанаев; докт. фил. н., проф., чл.-корр. НАН РК Б.А. Жакып; докт. фиолол. н., проф., академик НАН РК У.К. Калижанов; докт. фил. н., проф., академик НАН РК Д. Камзабекулы; докт. ист. н., проф., академик НАН РК Д.П. Кожамжарова; докт. ист. н., проф., академик НАН РК М.К. Койгельдиев; докт. филол. н., проф., чл.-корр. НАН РК Ш. Курманбайулы; докт. ист. н., проф., чл.корр. НАН РК Ж.К. Таймаганбетов; докт. социол. н., проф., чл.-корр. НАН РК З.К. Шаукенова; д. филол. н., проф., чл.-корр. НАН РК А. Дербисали; доктор политических наук, проф., Бижанов А.К.; доктор ист. наук, проф., Кабульдинов 3.Е.; доктор филол. н., проф., член-корр. НАН РК Қажыбек Е.3.

Р е дак ци онны й с ов е т

академик НАН Республики Молдова Г. Белостечник (Молдова); академик НАН Азербайджанской Республики Н. Велиханлы (Азербайджан); академик НАН Республики Таджикистан Т.Н. Назаров (Таджикистан); академик НАН Республики Молдова А. Рошка (Молдова); академик НАН Республики Молдова Г. Руснак (Молдова); чл.-корр. НАН Азербайджанской Республики Ш. Мурадов (Азербайджан), член-корр. НАН Азербайджанской Республики 3.Сафарова (Азербайджан); д. э. н., проф. В.Н. Василенко (Украина); д.ю.н., проф. В.А. Устименко (Украина)

Известия Национальной академии наук Республики Казахстан. Серия общественных и гуманитарных наук. ISSN 2224-5294

Собственник: РОО «Национальная академия наук Республики Казахстан» (г. Алматы)

Свидетельство о постановке на учет периодического печатного издания в Комитете информации и архивов

Министерства культуры и информации Республики Казахстан № 10894-Ж, выданное 30.04.2010 г.

Периодичность 6 раз в год

Тираж: 500 экземпляров

Адрес редакции: 050010, г. Алматы, ул. Шевченко, 28, ком. 219, 220, тел. 272-13-19, 272-13-18, www:nauka-nanrk.kz / social-human.kz

(C) Национальная академия наук Республики Казахстан, 2018 г.

Адрес типографии: ИП «Аруна», г. Алматы, ул. Муратбаева, 75

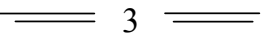


Chief Editor

\section{Honorary member of NAS RK \\ Balykbayev T.O}

Editorial board:

Doctor of economics, prof, academician of NAS RK Baimuratov U.B.; doctor of history, prof, academician of NAS RK Baipakov K.M.; doctor of philosophy, prof, academician of NAS RK Esim G.E.; doctor of philology, prof, academician of NAS RK Kirabayev S.S.; doctor of economics, prof, academician of NAS RK Koshanov A.K.; doctor of economics, prof, academician of NAS RK Naribayev K.N. (deputy editor-in-chief); doctor of philosophy, prof, academician of NAS RK Nyssanbayev A.N.; doctor of law, prof, academician of NAS RK Sabikenov S.N.; doctor of law, prof, academician of NAS RK Suleymenov M.K.; doctor of economy, prof, academician of NAS RK Satybaldin S.S.; doctor of history, prof, academician of NAS RK Abzhanov H.M; doctor of history, prof, corresponding member of NAS RK Abuseitova M.H.; doctor of history, prof, academician of NAS RK Baitanaev B.A.; doctor of philology, prof, corresponding member of NAS RK Zhakyp B.A.; doctor of philology, prof, academician of NAS RK Kalizhanov U.K.; doctor of philology, prof, academician of NAS RK Hamzabekuly D.; doctor of history, prof, academician of NAS RK Kozhamzharova D.P.; doctor of history, prof, academician of NAS RK Koigeldiev M.K.; doctor of philology, prof, corresponding member of NAS RK Kurmanbaiuly Sh.; doctor of history, prof, academician of NAS RK Taimaganbetov J.K.; doctor of sociology, prof, corresponding member of NAS RK Shaukenova Z.K.; doctor of philology, prof, corresponding member of NAS RK Derbisali A.; doctor of political science, prof Bizhanov A.K; doctor of History, prof Kabuldinov Z.E.; doctor of philology, prof, corresponding member of NAS RK Kazhybek E.Z.

\section{Editorial staff:}

Academician NAS Republic of Moldova Belostechnik.G (Moldova); Academician NAS Republic of Azerbaijan Velikhanli N. (Azerbaijan); Academician NAS Republic of Tajikistan Nazarov T.N. (Tajikistan); Academician NAS Republic of Moldova Roshka A. (Moldova) Academician NAS Republic of Moldova Rusnak G. (Moldova); Corresponding member of the NAS Republic of Azerbaijan Muradov Sh. (Azerbaijan); Corresponding member of the NAS Republic of Azerbaijan Safarova Z. (Azerbaijan); Associate professor of Economics Vasilenko V.N. (Ukraine), Associate professor of Law Ustimenko V.A. (Ukraine)

News of the National Academy of Sciences of the Republic of Kazakhstan. Series of Social and Humanities. ISSN 2224-5294

Owner: RPA "National Academy of Sciences of the Republic of Kazakhstan" (Almaty)

The certificate of registration of a periodic printed publication in the Committee of information and archives of the Ministry of culture and information of the Republic of Kazakhstan N 10894-Ж, issued 30.04.2010

Periodicity: 6 times a year

Circulation: 500 copies

Editorial address: 28, Shevchenko str., of. 219, 220, Almaty, 050010, tel. 272-13-19, 272-13-18, www:nauka-nanrk.kz / social-human.kz

(C) National Academy of Sciences of the Republic of Kazakhstan, 2018

Address of printing house: ST "Aruna", 75, Muratbayev str, Almaty 
N E W S

OF THE NATIONAL ACADEMY OF SCIENCES OF THE REPUBLIC OF KAZAKHSTAN

SERIES OF SOCIAL AND HUMAN SCIENCES

ISSN 2224-5294

https://doi.org/10.32014/2018. 2224-5294.3

Volume 5, Number 321 (2018), 19 - 25

UDC 7.067

A.T. Kulsarieva, M.E. Sultanova, Zh.N. Shaigozova

${ }^{1}$ Abai Kazakh National Pedagogical University, Almaty, Kazakhstan

E-mail:aktolkyn777@mail.ru, madina-sultanova@yandex.ru, zanna_73@mail.ru

\title{
FOLKLORE AND IDENTITY: HISTORY, MEMORY AND MYTH-MAKING IN THE MODERN VISUAL CULTURE OF KAZAKHSTAN
}

\begin{abstract}
The culture plays an essential role in the process of strengthening of the self -identity. Art creativity and visual art is a sensitive and truthful barometer that visually demonstrates the true state of things. The themes, events, heroes, promises are the basis of the art work, they are clearly or indirectly expressed as a kind of projection of the most relevant cultural trends in society.

The article explores the place, significance and authenticity of traditional folklore and historical subjects in the contemporary pictorial arts of Kazakhstan (painting, graphics and sculpture). The authors consider folklore as not just an interesting and distinctive phenomenon thatis capable for decorating any subject, but an important indicator which reflects the complex and often contradictory processes of the formation and strengthening of the nation identity.

The problematic field of the study is the results of two national art competitions "Kazakh folk epic. History and traditions of the Kazakh people "(2012) and "Babalar ansagan Tauelsizdik"(" Independence, bequeathed by ancestors ") (2016), which are organized by the A. Kasteev State Museum of Arts of the Republic of Kazakhstan under the patronage of the Ministry of Culture and Sports of the Republic of Kazakhstan. These most large-scale and prestigious events for a quarter of the century of Independence, in addition to an obvious picture of the artistic life state in the country, also convincingly demonstrate the degree of knowledge and awareness of the society about own historical and cultural heritage.

The theoretical and methodological basis of the article is artistic-philosophical and cultural-historical methods, the hermeneutical basis of which allows to make a more comprehensive look at the problem of figurative and semantic interpretations, also an axiological method capable for revealing the value orientations of modern culture.

The result of the article is an analysis of the socio-cultural potential of visual arts in the process of implementing some key tasks of Modernization 3.0 and the State Program "Ruhani Zhangiru", exactly, the preservation of own culture, national identity and national code.
\end{abstract}

Keywords: folklore and history, visual arts, identity, Kazakhstan.

Introduction. Formation of national self-identification is a complex process, which takes place at the crossword of many factors. In Kazakhstan, a young independent state, the strengthening of identity depends on such key elements as the knowledge of one's own history and the activity of socio-cultural memory, the systemic development of which is "the most important ideological function of the state" [1, 265]. Creation and promotion of new values that can unite history and reality is one of the priorities of modern cultural policy, designed to unite the people of Kazakhstan even more. The visual arts play an important role in solving this problem (sculpture, painting, drawing). And the last one has always been a powerful ideological tool, which forms and transmits the necessary meanings.

Traditional folklore links historical and cultural memory in many ways. The degree of presence of folkloric beginning in the society life, its "woven" into the real picture of the world demonstrates the stability of the cultural code. Folklore as an important element of cultural memory is designed to recreate the history, saturate symbolic meaning of symbolic events and people. According to J. Assman this is a process that unites individual identities into a collective identity and cementing it $[2,43,55]$. A. Dandes considered folklore as a kind of "mirror of culture" and an indicator of identity [3,54], [4, 140-150].

The main goal of the article is to analyze the degree of comprehension by the society of its own historical and cultural heritage through a conscious appeal to traditional folklore and historical subjects.

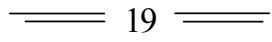


Research focuses on the results of the republican (2012) and national (2016) art competitions - the two largest and most prestigious events in the creative life of the country since independence.

We suppose that the tasks put forward to the competition participants can be considered as a kind of "state order". And the results of these events reveal not only the professional level of the domestic art community, but also the measure of its immersion in their cultural code.

At the moment, one cansingled out a certain number of clichés which "wandering" from one work to another. Usually these are pathos scenes, the historicity of which, like a belonging to some traditional folklore motif, can be questioned by the professional scientific community. Although any author has the right to artistic fiction, but free treatment of historical and folklore material is fraught with inevitable myth-making.

It should be emphasized that the intention of the authors of article does not include an appeal for criticism to certain specific personalities. We need an analytical look at the subject and figurative language of the works submitted to the competitions, to highlight the most stable images and plots on basis of which artists and sculptors construct their era.

Methods. The methodological basis of the article is the artistic-philosophical and cultural-historical methods, their hermeneutical potential allows to see more objectively the features of figurative and semantic interpretations. The axiological method helps to identify the value orientations of modern Kazakhstani culture. Also, the authors used analytical, retrospective and comparative-historical approaches.

Results. After gaining an independence Kazakhstan faced a global task of creating and promoting a national idea. The multiculturalism became a fundamental element in the formation of the cultural identity of Kazakhstan in 1990-2000s. Considering the expressed polytechnic composition of Kazakhstan people, multiculturalism has great potential for further active socio-cultural development.

Today multiculturalism in many respects is the semantic core of the state cultural policy of Kazakhstan, on its basis a new cultural identity is being constructed for a quarter of a century. And although this process is very complicated and ambiguous, it confidently moves forward[5,173-174], [6, 495], [7, 267].

Kazakhstan faces a few global challenges, some of which can be substantially resolved through well thought-out and balanced mechanisms of cultural policy. The issue of preserving identity has a paramount importance in Kazakhstan as for most states with a "colonial heritage". And here cultural identity and art that translates its values are the most effective tools [8, 208-209].

Independence has largely changed the strategy for the development of visual art. The era when everything was "impossible" eclipsed the time "everything is possible." The Kazakhstani creative community actively "joined" the global world. Many national artists (especially the late 90's early 2000's), striving to stand out, focused on originality. The idea of "returning to the origins" was understood literally, which was expressed through the large-scale exploitation of "national originality."

Often very professionally written / fashioned horses, batyrs, wolves, golden eagles, etc. have external effectiveness, but they are devoid of inner meaning, logic, imaginative content. Also, often we see a weak, and sometimes a complete lack of knowledge of traditional folklore and ornaments, an arbitrary interpretation of historical facts.

All this complicatedly affect the plot-semantic dimension of a work and / or creative credo of the artist. Such kind of precedents are appeared more and more, and they reflect a real picture of the representation and understanding by the society of its cultural code. We believe that the potential threat based on the transmission of "wrong" stories through different types of art, and here the special place is assigned to the visual types as the most demonstrated and popular.

In 2012, A. Kasteev State Museum of Arts of the Republic of Kazakhstan (further SMA RK) and ArLine company initiated the first republican creative contest "Kazakh national epic. History and traditions of the Kazakh people". This large-scale cultural project was devoted to the Independence Day of the Republic and its work was dedicated to the creation of high artistic paintings, significant in content and technical performance.

The competition was aimed at popularizing academic art, that's why Kazakh professional artists, which have completed higher or secondary specialized art education, were invited to participate. The works should have been created no earlier than 2012, exclusively in a large format, oil technology and a realistic manner. 
Despite of its standard formal requirements It is not difficult to see the essence of the competition: it is not as the "popularization of Domestic art" as the desire to see the true trends in the development of modern artistic consciousness of Kazakhstan as a projection of national identity.

We also believe that another goal of the competition was the desire to induce the country's creative elite to create highly professional works, which not only worthy of decorating the best museums but capable to become as chrestomathy art works and powerful means of translating spiritual values and aesthetic expression of different facets of the national idea. In this case, folklore was a specific identification marker, expressing one of its most vivid manifestations - the traditional epic.

The authoritative jury allowed to participate one hundred and seven people in the competition, whose canvases satisfied all parameters: theme, size, manner and material. All works were available for public viewing, first in the halls of the State Art Museums of RK, then on the pages of the exhibition catalog.

It was interesting how the artists imagined the task. The majority of participants preferred abstract standard subjects on the "national" theme like rituals, customs and holidays (dastarkhan, cutting of puts, celebration of forty days for a newborn, etc.); household scenes (guests - refreshments, cooking, mother and baby, jailau); pathos events (hunt hunting, proclamation into khans, batyr'soaths, soldier'sfarewell, etc.); allegorical / symbolic subjects (heritage, shamanism, long road, eternal nomadic life, etc.).

Analyzing the subject of the works, it was obvious that the general theme put forward by the organizers was "Kazakh folk epic". History and traditions of the Kazakh people "were most often represented by illustrations of customs and traditions. It is important that it was epos, not just epic, which was required, which in turn neither had sufficient credibility in most works nor was totally absent from the position of art criticism. Only few contestants directly appealed to the Kazakh epic.

Three works - "Deep. Baluen Sholak and Galiya "(author Dosbol Kasymov)" Adyraspan "(author Azhibekuly Kazakbai) and "Khan's hunting "(author Yesengali Sadyrbaev) shared three prizes. Seven works - "Kambar batyr", "Bayan", "Abylai Khan. Khan elections", "Besik orda "," Batyr babalar "," Dedication to the Kazakh soldiers who fell for their native homeland. Anirakay battle "," Zheti kazyna "were awarded with encouraging places.

It should be noted that nine of ten winner artists are representatives of the so-called generation $\mathrm{X}$ (all born between 1960-80). Their youth and creative development happened to be in the 80-90s of the twentieth century - the time of "stagnation" and its fundamental changes. These painters are distinguished by the "old" (professional) school, a stable picture of the world, a certain knowledge of traditional folklore and its perception as an important element of cultural memory $[9,60]$.

In general, the jury and visitors of the contestant's exhibition noted that, firstly, the art level of the paintings was lower than expected; secondly, the required epic-folkloric principle in most works is not expressed / misunderstood / not felt. The first point we explain that the modern Kazakh school of academic realistic painting is experiencing a certain stagnation, often giving way to salon and actual (conceptual) art. In the second case, we see alarming signs of a weakening of ethnic memory, as many works demonstrate superficial ideas about traditional culture, folklore, national history and their interrelation.

This competition was the first, and, despite of certain inconsistencies between the desired and the real had important results:

- there were exposed long overdue ideological, plot and technical problems in the creative environment;

- The open format of the competition allowed young artists (especially from regions) to test themselves on a high professional platform;

- experts of the art, culture and education fields (history, ethnography, literature, cultural studies, art education, art) faced the issue of conceptual changes in study programs at different levels and the need for serious, systematic research in the field of their own intangible cultural heritage and ways of its transmission.

We would like to mention one more detail: we think this contest for the first time clearly indicated the problem of the responsibility of the author's art work. For some reason, the society persistently believes that the artist as a kind of "vessel of God" can be guided only by his talent and vision. All plots and heroes chosen by him, even on historical themes, become "artistic reminiscence", which automatically removes the question of the potential "secondary" of figurative-semantic content and its authenticity. 
We supposed that especially in such areas as history and folklore, artists who intends to broadcast important moments (sometimes key events that form the national historical narrative) should have a high degree of moral obligations in front of society.

Four years later, in March 2016, the Ministry of Culture and Sports of the Republic of Kazakhstan and the A. Kasteev State Museum of Arts announced the National competition for the creation of works of painting and sculpture, dedicated to the history of the Kazakh people "Babalar ansagan Tauelsizdik" ("Independence, bequeathed by ancestors").

The competition was dedicated to the significant date of the 25th anniversary of the country's Independence. This project considered the experience of past years, the organizers developed objective requirements, indicating the purpose, objectives and recommended ways for their implementation. The results of the contest were available for public viewing in the format of two large-scale exhibitions in Astana and Almaty, as well as in the pages of the colorful catalog.

So, the goal was "to promote patriotic education through methods of artistic imagery and the embodiment of important historical events and personalities of our state in the context of the values of the national idea" Mangilik El ". Improvement and enhancement of professional artistic level of art masters, creating a competitive environment for artists". The artists as historians and scholars, writers and philosophers were declared chroniclers of history, spiritual culture, the life of the nation and the country [10].

The key mission of the contest was the formation of single cultural space of the country and a new comprehension of the history of Kazakhstan people through stimulating the interest of the domestic creative community to historical genre.

We emphasize that in addition to standard conditions for contestants, professional artistic education, novelty of works (not earlier than 2016), realistic manner, canvas-oil (for painting), bronze-aluminum marble (for sculpture), large works, were announced two more important and principled wishes: the plots should be specific historical episodes of national history before the beginning of the twentieth century; the priority will be works where the author can originally, sensibly and convincingly show the not so popular stories of the history of Kazakhstan people.

In contrast to the competition in 2012, there were supposed to conduct two qualifying stages. On the first, sketches of future works were considered and approved. The sketch must necessarily be accompanied at least by two-page explanatory note-justification for the historiography of the selected plot and the author's conceptual design. At the second stage, the organizing committee determined the work that responded all the requirements and allowed to participate in the competition.

Considering the importance and scope of the competition tasks, as well as the degree of responsibility of the masters, the SAM RK organized an open lecture-hall for all potential participants of the contest inviting leading historians and art historians of the country. There were several lectures on the history of the Kazakh Khanate and New Times (Speaker -expert on the social and political history of Kazakhstan, problems of pre-revolutionary and foreign historiography, candidate of historical sciences Erofeeva I.V), specific historical genre in the visual arts system - professor of T. Zhurgenov KazNAA, candidate of art history Baturina O.V).

It should be noted that one third of the works were rejected at the first stage. The main reason for this was, in addition to technical issues (size, manner), thematic inconsistency with the tasks of the project. So, for example, in the presence of the necessary artistic professionalism, some authors ignored the specific plot requirements of the competition and again turned to the popular "national" motives (dastarkhans, caravans on the Silk Road, batyr fights, nomadic events, etc.). Some of the masters could not provide a clear and historically objective explanatory note. Some artists experienced obvious difficulties with realistic academic technique or were professionally weak.

The hard selection made this competition a serious national project. The works admitted to participation in most cases showed that Kazakh artists were much more consciously and responsibly concerned with the state task.

So, except standard pathos stories (we think here more meaningful), the masters focused on really concrete and non-popular historical episodes and heroes (The Battle of Bulent, The Reception of Russian Ambassadors by Khan Abulkhair, The Holodomor, Orazmukhamedkhan Kasimovsky at the reception of Tsar Boris Godunov "," Mission of the Russian Ambassador A.I Tevkilev at the rate of Abulkhair Khan "," Ketbuga "," Shynkozha batyr "," Satay batyr "," Akhan seri", "Kozhbanbet bi", etc. ). 
Some participants, understanding of all the semantic, figurative and emotional complexity, turned to the tragic pages of the people history and could show this clearly and convincingly ("Aktaban shubirindi", "Holodomor-bread", "Oh my people (Elim-ay)" "The shooting of the insurgents", etc.).

Critically analyzing the results of this competition, it is obvious that, despite the ambitiousness of this project, the national status, prestige (big prizes to winners, prize works remain in the collection of the State Museum of the RK, the opportunity to significantly increase their authority, etc.)the number of participants was less than in 2012. Among 90 declared masters, only 67 could overcome the qualifying stage.

We explain this by the complexity of the requirements and responsibility that imposed on potential participants. Not all painters and sculptors who are now relatively well-known in the national creative community, specialize in a quality realistic manner of performance. The masters who seriously work in the historical genre and avoids the clichéd salon plots are even less.

The triptych "Aktaban shubyryndy" (author Dauren Kasteev) won the first place, the second and third places were won by the works "Visit of Kuzym Sultan to forge" (by Meirbek Nurgozhin) and "On the eve of the formation of the Golden Horde" (author Aset Zhakypbek). The "Holodomor - Bread" painting (author Dauren Makin) received an encouraging prize.

"Aktaban shubyrindy" ("the years of the great disaster") is a real event of the 18th century, a kind of historical watershed for the Kazakh people. This tragic breakthrough period of "getaway, while the soles did not turn white" played a key role for the people, who found the strength to unite and win. Widely known in the oral folklore tradition, this topic has never become a plot for visual art.

"Visiting the Forge of Kassym Sultan" is a calm, peaceful work. There is no authenticity here, the plot can be considered as a household one. But this canvas in its figurative and semantic structure immediately recalls the best examples of foreign realistic painting of the XIX century. The forge is the place where the victory is forged, and Kasim Sultan is one of the six men in the smithy. The artist could show the masculinity, greatness of the warrior without the standard stamps (white koshmas, crowds of subjects, brocade gowns, etc.). The boundless steppe on the horizon, the fire what tamed by strong hands, the cold shine of steel ammunition, the faithful horse and the stern male fraternity of equal strength and spirit are the true message of this work.

"On the eve of the Golden Horde formation" - a more symbolic theme than realistic (here they mean not the manner, but the imagery). But the work "Holodomor - Bread" is extremely penetrating and persuasive in its restrained tragedy. We think that the master was able to visualize this terrible period in our history and satiate it with epic.

This project needed historical authenticity, a considerable degree of scientific and high artistic professionalism. Maybe not all goals have been achieved, but the following results are certainly significant:

- Young artists (generation Y) appeared among the prize-winners of the competition;

- the composition of participants significantly rejuvenated;

- some well-experienced masters decided only to participate in the final exhibition, but not in the competition;

- Some young participants, in contrast to many experienced and well-deserved, tried to exactly perform all the conditions of the competition, especially the plot requirements.

Conclusion. Today one of the most important issues in the field of artistic creativity and culture is: Is the art able to independently form new models of sociocultural and political identity as well as reflecting them? $[11,38]$. This problem is especially relevant for young states seeking harmonization ways for national identity, identity and civil rights.

The results of the two competitions, with a difference of four years, show a positive trend. Firstly, such large projects were carried out for the first time and largely revived the cultural environment as a whole (artists painted the pictures, journalists and the public actively participated in discussion, art historians, culture experts and teachers received food for thought); secondly, many problem areas were revealed in the comprehension of national history and cultural heritage; Thirdly, during these several years many artists (especially young people) began to understand the importance of their capabilities and their mission in strengthening the national idea.

The appeal of creative people to history and heritage, their serious study, the desire for authenticity of subjects, meanings and entourage, greatly influences the reduction of mythological tendencies, relieves 
excessive pathetic. In order to promote the nation's self-consciousness, it is necessary to create art works which are meaningful from an artistic and historical point of view and capable for becoming specifically textbook.

We mean their value as not only museum exhibits, but as bright and memorable confirmations of important facts from textbooks of history, archeology, cultural studies and art history. We know many such examples. At one time, the civil and creative activity of the artists formed in Russia a powerful visual basis for progressive ideology. New generations of young people recognize and remember their history and folklore heritage through the paintings of I. Repin, V. Surikov, V. Vasnetsov, I. Kramskoy, Perov and other artists of that period.

The images of Chokan Valikhanov, Amangeldy Imanov, the young Abai Kunanbayev, which were created in the last century by A. Kasteev, today have chrestomatic status. We cannot imagine our folk heroes differently. And when we read the Kazakh epics, we see Alpamys and Kobland Batyrsas they were painted by V. Sidorkin and I. Isabaev.

Art is one of the most effective methods of drawing attention to the needs and problems of society. A sharpened intuition and a special vision place artist in the vanguard of the sociocultural development of society. Therefore, their role in the formation and promotion of the most important values and meanings is extremely effective. But the artist at the same time is able not only to display something that he observes. Having a talent, the master can express (sometimes even unconsciously) something that has not expressed yet, but already exists.

\section{REFERENCES}

[1] Kundakbayeva Zh. V poiskakh istoricheskogo narrativa Kazakhstana: «dialog pamyatey» ili «natsional'naya pamyat' // V kn.: Natsional'nyye istorii na postsovetskom prostranstve - II. - Moskva: Fond Fridrikha Naumanna, AIRO-KHKHI, 2009. S. 295-296. (In Russian).

[2] Assman Ya. Kul'turnaya pamyat': Pis'mo, pamyat' o proshlom i politicheskaya identichnost' v vysokikh kul'turakh drevnosti. M.: Yazyki slavyanskoy kul'tury, 2004. 368 s. (In Russian).

[3] Meaning of Folklore: The Analytical Essays of Alan Dundes. Edited and Introduced by Simon J. Bronner. 2007. Published by: Utah State University Press, University Press of Colorado. P. 443 DOI: 10.2307 / j.ctt4cgrzn (in Eng). Eng).

[4] Dundes A. Defining Identity through Folklore //Journal of Folklore Research Vol. 21, No. 2/3, 1984, pp. 149-152. (in

[5] Abazov R., Khazbulatov A. Experimenting with Multiculturalism and Globalization: The Case of Kazakhstan's Cultural Policies. // Il Nodo di Gordio. 2015. No. 8, - P. 170-179. (in Eng).

[6] Schatz E. The Politics of Multiple Identities: Lineage and Ethnicity in Kazakhstan. // Europe-Asia Studies. 2000, Vol. 52, No. 3, pp. 489-506. (in Eng).

[7] Mukazhanova K. The Politics of Multiple Identities in Kazakhstan: Current Issues and New Challenges. / Multiple Identities: Migrants, Ethnicity, and Membership. Edited by Paul Spickard. 2013, USA. Indiana University Press. pp. 265-289. (in Eng).

[8] Mulcahy K. Identity and Cultural Policy // Understanding the Arts and Creative Sector in the United States, 2008, USA. Rutgers University Press, pp. 197-212. (in Eng).

[9] Sultanova M., Mikhailova N., Amanzholova D. Between the East and the West: reflections on the contemporary art of Kazakhstan, Electronic Journal of Folklore, Estonia. Vol. 63, 2016. p.45-65.DOI: 10.7592/ FEJF2016.63 (in Eng).

[10] National competition for the creation of works of painting and sculpture, dedicated to the history of the Kazakh people "Babalar ansagan Tauelsizdik" ("Independence, bequeathed by ancestors"). http://mks.gov.kz/rus/informery/centralnyi apparat/departament_kultury iskusstva/tvorcheskie_konkursy dki/?cid=0\&rid=2012 (In Russian).

[11] Turner C., Webb J. Art and human rights: Contemporary Asian contexts. - Manchester: Manchester University Press, 2016. Pages: 232 (in Eng).

\section{А.Т. Құлсариева, М.Э. Султанова, Ж.Н. Шайгозова}

Абай атындағы Қазақ Ұлттық Педагогикалық Университеті, Алматы, Қазақстан

\section{ФОЛЬКЛОР ЖӘНЕ СӘЙКЕСТІЛІК: ҚАЗАҚСТАННЫН ҚАЗІРГІ ЗАМАНҒЫ МӘДЕНИЕТІНДЕГІ ТАРИХ, ЖАДЫ ЖӘНЕ АНЫЗ ШЫҒАРМАШЫЛЫҒЫ}

Аннотация. Өзінің сәйкестілігін нығайту барысында мәдениет аса маңызды рөл атқарады. Көркем шығармашылық және де нақты айтқанда, визуалды өнер заттардың шынайы жағдайын көрсететін сергек және дұрыс барометр болып табылады. Анық немесе жанама берілген тақырыптар, оқиғалар, кейіпкерлер, түрткі - өнер туындысының негізі, әлеуметте ең өзекті мәдени трендтердің өзгеше кескіні рөлін атқарады. 
Мақалада Қазақстанның қазіргі заманғы бейнелеу өнеріндегі (кескіндеме, графика және мүсін) дәстүрлі фольклорлы және тарихи сюжеттердің орны, мәні және түпнұсқалылығы зерттеледі. Авторлар фольклорды кез келген сюжетті бейнелейтін қызықты және ерекше феномені ретінде ғана емес, ұлттың сәйкестілігін қалыптастыру және нығайтудың күрделі және жиі қарама-қайшы болып келетін үрдістерін айқындайтын маңызды индикатор ретінде қарастырады.

Зерттеудің мәселелі өрісі Қазақстан Республикасы Мәдениет және спорт министрлігінің бастамасымен Ә.Қастеев атындағы Қазақстан Республикасының Мемлекеттік өнер мұражайымен ұйымдастырылған «Қазақ халық эпосы. Қазақ халқының тарихы мен дәстүрлері» (2012) және «Бабалар аңсаған Тәуелсіздік» (2016) атты екі ұлттық көркемдік байқаудың нәтижелері болып табылады. Тәуелсіздіктің ширек ғасыры ішіндегі осы ең ауқымды және беделді іс-шаралар еліміздің көркемдік өмірі жағдайының айқын жағдайынан басқа, әлеуметтің өзінің тарихи-мәдени мұрасын білу және түсіну дәрежесін көрсете алды.

Мақаланың теориялық-әдіснамалық негіздемесі ретінде герменевтикалық негізі бейнелі және мағыналы интерпретациялардың мәселесін көлемді қарастыруға мүмкіндік беретін көркемдік-философиялық және мәдени-тарихи әдістер, сонымен қатар қазіргі заманғы мәдениеттің құндылықты бағдарларын айқындай алатын аксиологиялық әдіс пайдаланылды.

Мақаланың нәтижесі 3,0 Жаңарту және «Рухани Жаңғыру» Мемлекеттік бағдарламасының кейбір негізгі міндеттерін жүзеге асыру барысында визуалды өнердің әлеуметтік-мәдени әлеуетін талдау, нақты айтқанда өз мәдениетін, ұлттық сәйкестілігін және ұлттық кодты сақтау болып табылады.

Түйін сөздер: фольклор және тарих, визуалды өнер, сәйкестілік, Қазақстан.

\section{А.Т. Кулсариева, М.Э. Султанова, Ж.Н. Шайгозова}

${ }^{1}$ Казахский национальный педагогический университет имени Абая, Алматы, Казахстан

\section{ФОЛЬКЛОР И ИДЕНТИЧНОСТЬ: ИСТОРИЯ, ПАМЯТЬ И МИФОТВОРЧЕСТВО В СОВРЕМЕННОЙ ВИЗУАЛЬНОЙ КУЛЬТУРЕ КАЗАХСТАНА}

Аннотация. В процессе укрепления собственной идентичности культура играет чрезвычайно важную роль. Художественное творчество и, в частности, визуальное искусство является чутким и правдивым барометром, наглядно демонстрирующим истинное положение вещей. Явно или опосредовано темы, события, герои, посылы, - основа произведения искусства, выступают своеобразной проекцией самых актуальных культурных трендов в социуме.

Статья исследует место, значение и аутентичность традиционных фольклорных и исторических сюжетов в современном изобразительном искусстве Казахстана (живопись, графика и скульптура). Авторы рассматривают фольклор не просто интересным и самобытным феноменом, способным украсить любой сюжет, но важным индикатором, отражающим сложные и часто противоречивые процессы формирования и укрепления идентичности нации.

Проблемным полем исследования являются итоги двух национальных художественных конкурсов «Казахский народный эпос. История и традиции казахского народа» (2012) и «Бабалар аңсаған Тәуелсіздік» («Независимость, завещанная предками») (2016), организованных Государственным музеем искусств Республики Казахстан им. А. Кастеева под патронажем Министерства культуры и спорта Республики Казахстан. Эти самые масштабные и престижные мероприятия за четверть века Независимости помимо очевидной картины состояния художественной жизни страны еще и убедительно демонстрируют степень знания и осознания социумом собственного историко-культурного наследия.

Теоретико-методологической основой статьи выступают художественно-философский и культурноисторический методы, герменевтическая основа которых позволяет более объемно взглянуть на проблему образных и смысловых интерпретаций, а также аксиологический метод, способный выявить ценностные ориентиры современной культуры.

Результатом статьи видится анализ социокультурного потенциала визуальных искусств в процессе осуществления некоторых ключевых задач Модернизации 3.0 и Государственной Программы «Рухани Жаңғыру», а именно - сохранении своей культуры, национальной идентичности и национального кода.

Ключевые слова: фольклор и история, визуальные искусства, идентичность, Казахстан

Information about authors:

Kulsarieva A.T. - Abai Kazakh National Pedagogical University, Almaty, Kazakhstan, https://orcid.org/0000-0002-7867430X;

Sultanova M.E. - Abai Kazakh National Pedagogical University, Almaty, Kazakhstan, https://orcid.org/0000-0002-79591856; 7598

Shaigozova Zh.N. - Abai Kazakh National Pedagogical University, Almaty, Kazakhstan, https://orcid.org/0000-0001-8167- 


\section{МАЗМҰНЫ}

Алтыбаева С.М., Савындыков Е.С. Көркем мәтін құрылымындағы мифопоэтикалық модельдеу және мәдени код...... 5 Сембиева Л.М., Мажитов Д.М., Карпиикая М.Е., Хамитова Д.М. Экономиканы жаңғырту жағдайындағы ЕАЭО елдерінің монетарлық жүесінін өзгеруі .....

Құлсариева А.Т., Султанова М.Э., Шайгозова Ж.Н. Фольклор және сәйкестілік: Қазақстанның қазіргі заманғы

мәдениетіндегі тарих, жады және аңыз шығармашылығы ........................................................................................... 19

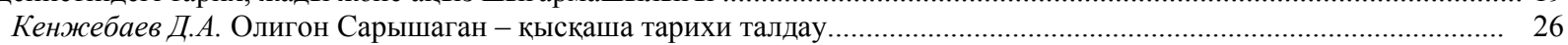

АбдулинаГ.А., БазарбаевА.Г. Ұйымдардағы адам ресурстарын басқарудың заманауи тұжырымдамалары................ 33

Авыбаев А.Н., Адибаева А.К. Геноцид туралы БҰҰ Конвенциясының қатысушы мемлекеттердің қылмыстық

заңнамаларындағы имплементациялық тетіктері: жалпы салыстырмалы талдау............................................................ 39

Ахметжанов Б., Тәжібекова К.Б., Шаметова А.А. Қазақстан көлік өнеркәсіптің дамуын талдау............................. 44

Аюпова 3.К., Құсайынов Д.Ө. Тәуелсіздік жағдайындағы қазақстан республикасының конституциялық-құқықтық

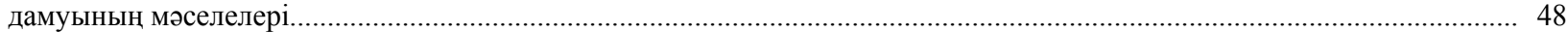

Нурпеисова А.А., Рей И.Ю., Бижанов Д.Т., Тлеужанова Д.А. Инновациялық өндірісді жасаудың процесін

бақылауының негізгі элементтері

Гиздатов Г.Г. Қазақстандық дискурсының құрылымы психолингвистиякалық зерттеу .

Ищанова Р.К. Мемлекеттік шығындарды басқару - мемлекеттің қаржылық тұрақтылығын қамтамасыз ету.............. 64

Мадышева А.М. Бикенова А.С., Елеусиз Л.Т. Білім саласындағы туристік қызметтер............................................. 68

Ескалиева А. Ж., Баймуханова М.Т., Ахмурзина Д.О. Әлеуметтік сала адам капиталының сапасын қолдаудың

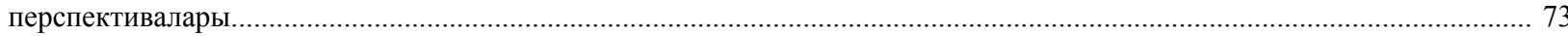

Мархаева Б.А., Козбахова Д.Л. Жауапкершілік орталық және трансферттік баға белгілеу............................................ 79

Сабирова Р.К., Утепкалиева К.М., Кабаков С.Б. Қазақстандағы ауыл шаруашылығы экономикасының

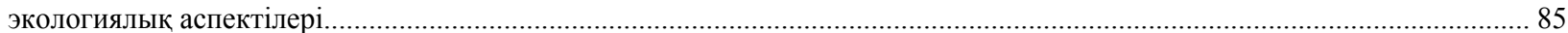

Тлесова Э., Хойч А., Кураш Н. Қазақстан республикасының ғылыми инновациялық потенциясы және оның

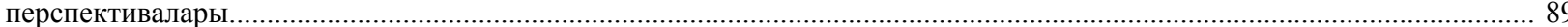

Хамитхан Н. Қазақстандағы банктік қызметтердің сапасын жақсарту жағдайында банкаралык басекелестік............ 95

Шалдарбеков Қ.Б., Муханова Г.С., Нурмухамбетова 3.С. Аймақтарды дамыту бағдарламаларын жүзеге асырудағы жобалық басқаруды қолданудың шетелдік тәжірибесі

КаратаеваА.М., Бердиярова Ж.С. Мемлекеттік қызметшінің әдептік мәдениеті және құқықтық мәдениеті

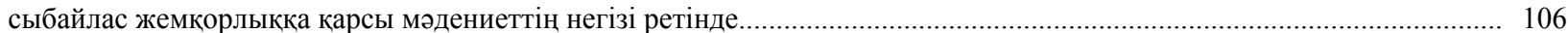

Алдабергенова А.А. Абсурд әдебиетін аударудың лингвомәдени аспектілері ................................................... 113

Стукач В. Ф., Байдалинова А. С., Сандыбаева Б. А. Қазақстанның қаржылық қауіпсіздігі......................................... 119

Баймаханова Д.М., Оспанова Д.А. Конституциялық-құқықтық сана - конституционализмнің маңызды

компоненті ретінде және оның адам құқықтары мәселелерін шешудегі рөлі................................................................. 126

Имангожина 3.А. Сланцевая революция: глобальный тренд на мировом энергетическом рынке............................. 137

Ракаева А.Н., Жуматаева Б.А., Успамбаева М.К., Доскалиева Б.Б. Экологиялық есеп қазақстандағы кәсіпорын экономикасының даму кезеңі ретінде

Нуржанова Г.И. Экономиканың аграрлық секторындағы еңбек әлеуетіне демографиялық фактордың әсері............ 147

Оспанова Д.А., Баймаханова Д.М. Қазақстан Республикасының кибер кеңістігін дамыту жағдайында мемлекеттік қызметтерді цифрландыруда әкімшілік-құқықтық қамтамасыз ету ................................................................................... 152

Pblсnекова М.О., Тлесова Э.Б., Хаитбаева Ф.К. Қазақстандағы тұрғын үй-коммуналдық шаруашылық қызметін

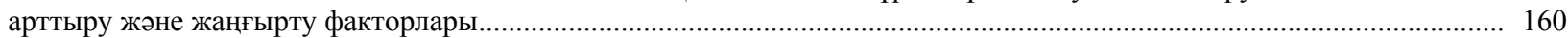

Султанова Г. Т. Аграрлық сектордың экспорттық әлеуетін дамытуға бағытталған үрдістер мен басымдықтар........ 166 


\section{СОДЕРЖАНИЕ}

Алтыбаева С.М., Сагындыков Е.С. Культурный код и мифопоэтическое моделирование в структуре художественного текста

Сембиева Л.М., Мажитов Д.М., Карпиикая М.Е., Хамитова Д.М. Трансформация монетарной системы стран

ЕАЭС в условиях модернизации экономики

Кулсариева А.Т., Султанова М.Э., Шайгозова Ж.Н. Фольклор и идентичность: история, память и мифотворчество

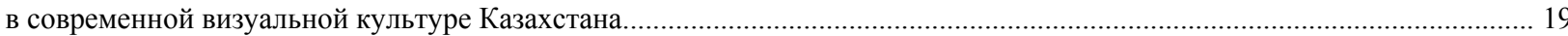

Кенжебаев Д.А. Полигон Сарышаган - краткий исторический анализ................................................................ 26

Абдулина Г.А., БазарбаевА.Г. Современные концепции управления человеческми ресурсами в организациях............ 33

Агыбаев А.Н., Адибаева А.К. Имплементационные механизмы Конвенции ООН о геноциде в уголовных

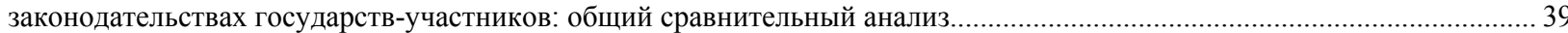

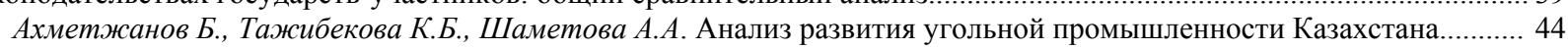

Аюпова 3.К., Кусаинов Д.У.Проблемы конституционно-правового развития республики Казахстан в условиях суверенитета ......

Нурпеисова А.А., Рей И.Ю., Бижанов Д.Т., Тлеужанова Д.А. Основные элементы управления процессом создания инновационной продукции ....

Гиздатов Г.Г. Психолингвистическое исследование концептов казахстанского дискурса......

Ищанова Р.К. Управление государственными расходами - как обеспечение финансовой устойчивости государства. 64

Мадышева А.М. Бикенова А.С., Елеусиз Л.Т. Туристские услуги в сфере образования................................................. 68

Ескалиева А. Ж., Баймуханова М.Т., Ахмурзина Д.О. Перспективы усиления качества человеческого капитала

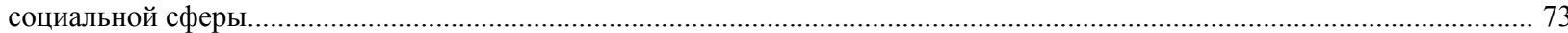

Мархаева Б.А., Козбахова Д.Л. Центр ответственности и трансфертное ценообразование....................................... 79

Сабирова Р.К., Утепкалиева К.М., Кабаков С.Б. Экологические аспекты экономики сельского хозяйства

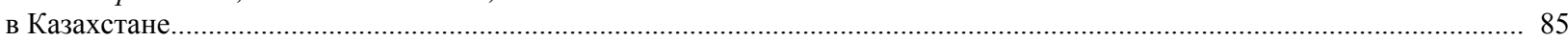

Тлесова Э., Хойч А., Кураш Н. Научно-инновационный потенциал республики Казкастан и его перспективы............ 89

Хамитхан Н. Межбанковская конкуренция в условиях повышения качества банковских услуг в Казахстане..............95

Шалдарбеков К.Б., Муханова Г.С., Нурмухамбетова З.С. Зарубежный опыт применения проектного управления

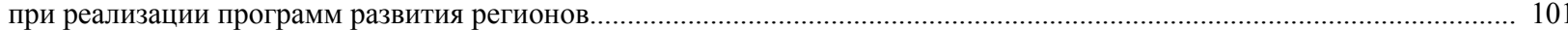

Каратаева А.М., Бердиярова Ж.С. Этическая культура и правовая культура государственных служащих

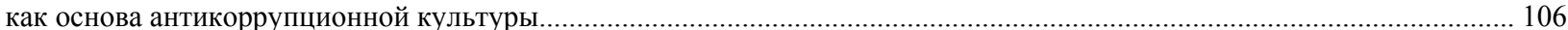

Алдабергенова А.А. Лингвокультурологические аспекты перевода литературы абсурда........................................... 113

Стукач В. Ф., Байдалинова А. С., Сандыбаева Б. А. Казахстанская финансовая безопасность................................... 119

Баймаханова Д.М., Оспанова Д.А. Конституционно-правовое сознание как важный компонент конституционализма

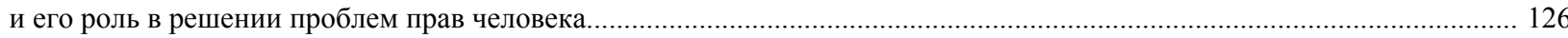

Имангожина 3.А. Сланцевая революция: глобальный тренд на мировом энергетическом рынке............................ 137

Ракаева А.Н., Жуматаева Б.А., Успамбаева М.К., Доскалиева Б.Б. Экологический учет как ступень развития

экономики предприятия в Казахстане............................................................................................

Нуржанова Г.И. Влияние демографического фактора на трудовой потенциал аграрного сектора экономики............ 147

Оспанова Д.А., Баймаханова Д.М. Административно-правовое обеспечение цифровизации государственных услуг в условиях развития кибер пронстранства республики Казахстан......

Рыспекова М.О., Тлесова Э.Б., Хаитбаева Ф.К. Факторы инновационной модернизации и совершенствования деятельности жилищно-коммунального хозяйства в Казахстане

Султанова Г. Т. Тенденции и приоритеты развития экспортного потенциала аграрного сектора... 


\section{CONTENTS}

Altybayeva S.M., Sagyndykov E.S. Cultural code and myth poetic modeling in the structure of the artistic text..................... 5 Sembiyeva L.M., Mazhitov D.M., Karpitskaya M.E., Khamitova D.M. Transformation of the monetary system of the eurasian economic UNION countries in the conditions of modernization of the economy......

Kulsarieva A.T., Sultanova M.E., Shaigozova Zh.N. Folklore and identity: history, memory and myth-making in the modern

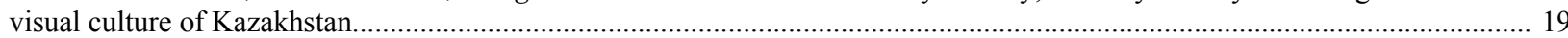

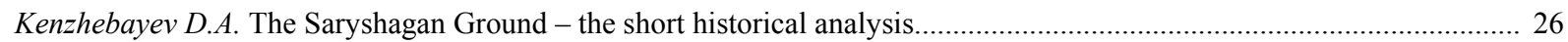

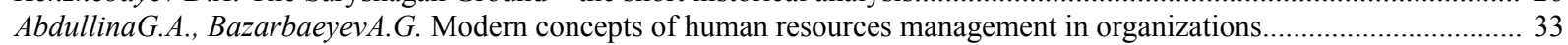

Agybayev A.N., Adibayeva A.K. Implementing mechanisms of the UN Convention on genocide in the criminal legislation

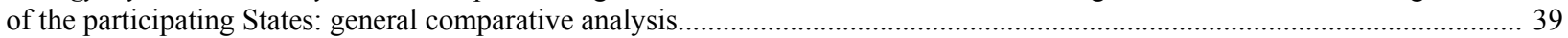

Akhmetzhanov B., Tazhibekova K.B, Shametova A.A. Analysis of development of the coal industry of Kazakhstan.............. 44 Ayupova Z.K., Kussainov D.U. Problems of constitutional and legal development of the republic of kazakhstan in the conditions of sovereignty......

Nurpeisova A.A., Rey I.Yu., Bizhanov D.T., Tleuzhanova D.A. Main elements of managing the process of creating innovation production.

Gizdatov G.G. Psycholinguistic study of the concepts of Kazakhstar

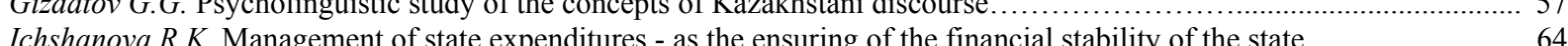

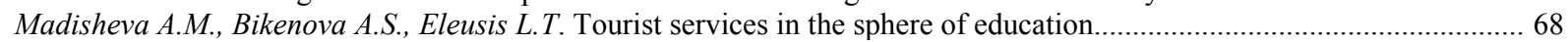

Eskalieva A. Zh., Baymukhanova M.T., Ahmurzina D.O. Perspectives of strengthening the quality of the human capital

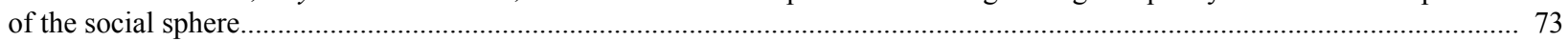

Markhayeva B.A., Kozbakhova D.L. A responsibility center and transfer pricing ................................................. 79

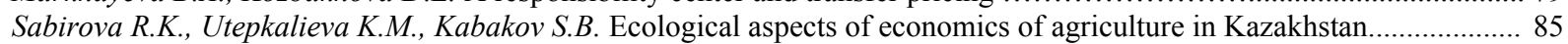

Tlessova E., Khoich A., Kurash N. Scientific innovation potential of the republic of Kazkahstan and its perspectives........ 89

Hamitkhan $N$. Interbank competition in conditions of improving the quality of banking services in Kazakhstan.................. 95

Shaldarbekov K., Mukhanova G., Nurmukhambetova Z. International practices in project management in implementing

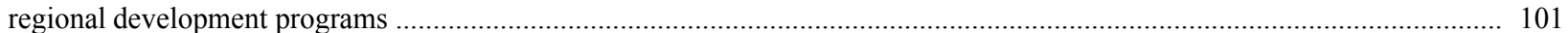

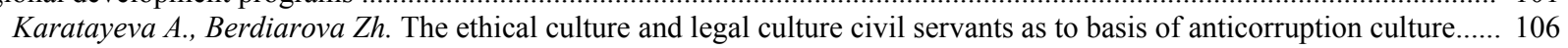

Aldabergenova A.A. Linguocultural aspects of translation of absurd literature.............................................................. 113

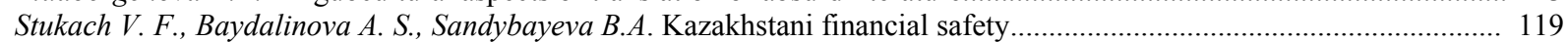

Baimakhanova D.M., Ospanova D.A. Constitutional and legal consciousness as an important component of constitutionalism

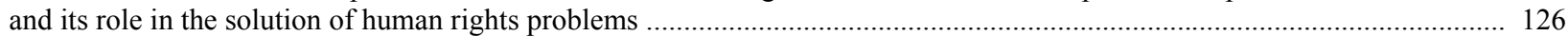

Imangozhina Z.A. Shale gas revolution: global trend in the world energy market..................................................... 137

Rakaeva A.N., Zhumataeva B.A., Uspanbayeva M.K., B.B.Doskalieva. Level of ecological report development in the economic of Kazakhstan's companies.

Nurzhanova G.I. Impact of demographic factors on labor potential of economy's agricultural sector

Ospanova D.A., Baimakhanova D.M. Administrative and legal support of digitalization of public services in the context of the development of cyber space in the republic of Kazakhstan....

Ryspekova M.O., Tlessova E.B., Khaitbayeva F. Factors of innovative modernization and improvement of activity

of housing and communal services in Kazakhstan.

Sultanova G. T. Trends and priorities for the development of export potential of the agrarian sector. 


\title{
PUBLICATION ETHICS AND PUBLICATION MALPRACTICE IN THE JOURNALS OF THE NATIONAL ACADEMY OF SCIENCES OF THE REPUBLIC OF KAZAKHSTAN
}

For information on Ethics in publishing and Ethical guidelines for journal publication see http://www.elsevier.com/publishingethics and http://www.elsevier.com/journal-authors/ethics.

Submission of an article to the National Academy of Sciences of the Republic of Kazakhstan implies that the work described has not been published previously (except in the form of an abstract or as part of a published lecture or academic thesis or as an electronic preprint, see http://www.elsevier.com/postingpolicy), that it is not under consideration for publication elsewhere, that its publication is approved by all authors and tacitly or explicitly by the responsible authorities where the work was carried out, and that, if accepted, it will not be published elsewhere in the same form, in English or in any other language, including electronically without the written consent of the copyrightholder. In particular, translations into English of papers already published in another language are not accepted.

No other forms of scientific misconduct are allowed, such as plagiarism, falsification, fraudulent data, incorrect interpretation of other works, incorrect citations, etc. The National Academy of Sciences of the Republic of Kazakhstan follows the Code of Conduct of the Committee on Publication Ethics (COPE), and follows the COPE Flowcharts for Resolving Cases of Suspected Misconduct (http://publicationethics.org/files/u2/New Code.pdf). To verify originality, your article may be checked by the originality detection service Cross Check http://www.elsevier.com/editors/plagdetect.

The authors are obliged to participate in peer review process and be ready to provide corrections, clarifications, retractions and apologies when needed. All authors of a paper should have significantly contributed to the research.

The reviewers should provide objective judgments and should point out relevant published works which are not yet cited. Reviewed articles should be treated confidentially. The reviewers will be chosen in such a way that there is no conflict of interests with respect to the research, the authors and/or the research funders.

The editors have complete responsibility and authority to reject or accept a paper, and they will only accept a paper when reasonably certain. They will preserve anonymity of reviewers and promote publication of corrections, clarifications, retractions and apologies when needed. The acceptance of a paper automatically implies the copyright transfer to the National Academy of sciences of the Republic of Kazakhstan.

The Editorial Board of the National Academy of sciences of the Republic of Kazakhstan will monitor and safeguard publishing ethics.

Правила оформления статьи для публикации в журнале смотреть на сайте:

$$
\begin{gathered}
\text { www:nauka-nanrk.kz } \\
\text { social-human.kz }
\end{gathered}
$$

\author{
Редакторы М.С. Ахметова, Т.А. Апендиев, Д.С. Аленов \\ Верстка на компьютере А.М. Кульгинбаевой \\ Подписано в печать 10.10.2018 \\ Формат 60x881/8. Бумага офсетная. Печать - ризограф. \\ 11,6 п.л. Тираж 500. Заказ 5.
}

